

\section{Daftar Isi (Table of Content) Journal of Government
Civil Society}

\begin{tabular}{|c|c|}
\hline \multirow{3}{*}{$1-30$} & $\begin{array}{l}\text { The Application of Social Movement as a Form of Digital Advocacy: Case of } \\
\text { \#TolakRUUPermusikan }\end{array}$ \\
\hline & Muhammad Ananda Alifiarry ${ }^{1}$, Bevaola Kusumasari ${ }^{1}$ \\
\hline & $\begin{array}{l}\left({ }^{1} \text { Department of Public Policy and Management, Faculty of Social and Political Sciences, }\right. \\
\text { Universitas Gadjah Mada, Indonesia) }\end{array}$ \\
\hline \multirow{3}{*}{$31-50$} & $\begin{array}{l}\text { Urban Resilience Strategy in the Climate Change Governance in Makassar } \\
\text { City, Indonesia }\end{array}$ \\
\hline & $\begin{array}{l}\text { Ihyani Malik }{ }^{1} \text {, Andi Luhur Prianto }{ }^{2} \text {, Abdillah Abdillah², Zaldi Rusnaedy }{ }^{3} \text {, } \\
\text { Andi Annisa Amalia }{ }^{4}\end{array}$ \\
\hline & $\begin{array}{l}\text { (' Department of Public Administration, Universitas Muhammadiyah Makassar, Indonesia) } \\
\text { (' Department of Government Studies, Universitas Muhammadiyah Makassar, Indonesia) } \\
\text { ( }{ }^{3} \text { Department of Government Studies, Universitas Pancasakti Makassar, Indonesia) } \\
\text { ( }{ }^{4} \text { Department of Architecture, Faculty of Engineering, Universitas Muhammadiyah } \\
\text { Makassar, Indonesia) }\end{array}$ \\
\hline \multirow{3}{*}{$51-62$} & $\begin{array}{l}\text { Collaboration Governance in The Development of Natural Based Tourism } \\
\text { Destinations }\end{array}$ \\
\hline & 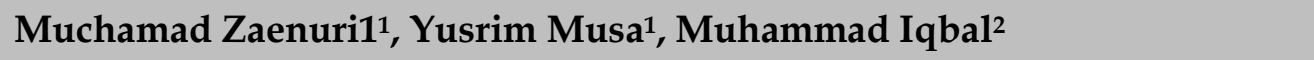 \\
\hline & $\begin{array}{l}\text { (1 Department of Government Affairs and Administration Universitas Muhammadiyah } \\
\text { Yogyakarta, Indonesia) } \\
\text { (2 Department of Political Science National Cheng Kung University, Taiwan, Province of } \\
\text { China) }\end{array}$ \\
\hline \multirow{3}{*}{$63-78$} & $\begin{array}{l}\text { Analysis of Mind Patterns and Work Culture in Government of West } \\
\text { Pasaman District }\end{array}$ \\
\hline & $\begin{array}{l}\text { Sri Andri Yani1 }{ }^{1} \text {, Etika Khairina1, Suswanta1, Mochammad Iqbal } \\
\text { Fadhlurrohman' }\end{array}$ \\
\hline & (1 Governmental Studies, Universitas Muhammadiyah Yogyakarta, Indonesia) \\
\hline \multirow{2}{*}{$79-90$} & $\begin{array}{l}\text { The Influence of Social Media (Instagram) of Bantul's General Election } \\
\text { Commissions on Voters Participation in the } 2019 \text { Elections }\end{array}$ \\
\hline & $\begin{array}{l}\text { Agus Priyanto', Eko Priyo Purnomo }{ }^{1,2} \text {, Mochammad Iqbal } \\
\text { Fadhlurrohman }^{1} \text {, Herry Fahamsyah", Etika Khairina }\end{array}$ \\
\hline
\end{tabular}


(1 Departement of Government Affairs and Administration, Universitas Muhammadiyah Yogyakarta, Indonesia)

(2 Jusuf Kalla School of Government, Universitas Muhammadiyah Yogyakarta, Indonesia)

Model Implementation Trap of Policy New Student Acceptance Zoning System in Makassar City

91 - 106 Nuryanti Mustari' ${ }^{1}$, Rudi Hardi ${ }^{1}$, Amir Muhiddin ${ }^{1}$

( ${ }^{1}$ Department of Government Studies, Faculty of Social and Political Sciences, Universitas Muhammadiyah Makassar, Indonesia)

Collaborative Urban Governance Model in Environmental Management of Industrial Area

Tri Sulistyaningsih"1, Saiman', Nofianda Fatimah Azzahra1, Nanda

$107-126$ Adityawan'2, Mohammad Jafar Loilatu ${ }^{3}$

( ${ }^{1}$ Department of Government Studies, Universitas Muhammadiyah Malang Indonesia) (2 Civil Engineering, Sepuluh Nopember Institute of Technology, Surabaya, Indonesia) ( ${ }^{3}$ Government Affairs and Administration, Universitas Muhammadiyah Yogyakarta, Indonesia)

Towards an Integration of Immigration and Customs Agency in Indonesia: A Step-by-Step Process

\section{7 - $144 \quad$ Ridwan Arifin' ${ }^{1}$, Intan Nurkumalawati ${ }^{1}$}

(1 Diploma Program of Immigration Administration, Polytechnic of Immigration, Indonesia) 


\title{
Model Implementation Trap of Policy New Student Acceptance Zoning System in Makassar City
}

\author{
Nuryanti Mustari ${ }^{*}$, Rudi Hardi ${ }^{1}$, Amir Muhiddin ${ }^{1}$ \\ ${ }^{1}$ Department of Government Studies, Faculty of Social and Political Sciences, Universitas Muhammadiyah \\ Makassar, Indonesia
}

*Email Correspondence: nuryantimustari@Unismuh.ac.id

\begin{abstract}
Implementing the zoning system in the 2019/2020 school year imposed by the Makassar city government through the Education Office caused various problems. This study's specific purpose is (1) To examine the characteristics of the New Student Acceptance problem of the zoning system, (2) explore the supporting capacity of the regulations, 3. non-regulatory environmental factors that affect the implementation of the PPDB zoning system. 4. Implementation trap of policy. The Research Method used is a qualitative method, and the appropriate type of research is a case study. The results showed that the New Student Acceptance problem zoning system characteristics, among others: Infrastructure readiness problems for online registration, Lack of socialization of PPDB system to prospective students and parents, thus confusing. The implementation trap of policy, the policy objective is too vague or broad to be converted into action, the target specification is not clearly defined due to weak guidelines on how goals can be achieved, or undefined standards or actions to be taken, either in implementing, or the target community. Finally, problems also arise when the chain of responsibility for implementing a policy is unclear.
\end{abstract}

Keywords: Implementation Trap Of Policy, Zoning System, PPDB

\begin{abstract}
ABSTRAK
Penerapan system zonasi pada tahun ajaran 2019/2020 yang diberlakukan pemerintah kota Makassar melalui Dinas Pendidikan menimbulkan berbagai permasalahan. Tujuan khusus penelitian ini adalah (1) Untuk meneliti karakteristik masalah Penerimaan Siswa Baru dari system zonasi, (2) mengeksplorasi daya dukung peraturan, 3. Factor lingkungan non-regulasi yang mempengaruhi penerapan system zonasi PPDB. 4. Perangkap implementasi kebijakan. Metode Penelitian yang digunakan adalah metode kualitatif, dan jenis penelitian yang sesuai adalah studi kasus. Hasil penelitian menunjukkan bahwa karakteristik system zonasi masalah Penerimaan Siswa Baru antara lain: Masalah kesiapan infrastruktur untuk pendaftaran online, Kurangnya sosialisasi sistem PPDB kepada calon siswa dan orang tua, sehingga membingungkan. Jebakan implementasi kebijakan, tujuan kebijakan terlalu kabur atau luas untuk dikonversi menjadi tindakan, spesifikasi target tidak didefinisikan dengan jelas karena pedoman yang lemah tentang bagaimana tujuan dapat dicapai, atau standar atau tindakan yang tidak terdefinisi untuk diambil, baik dalam menerapkan, atau komunitas target. Akhirnya, masalah juga muncul ketika rantai tanggung jawab untuk menerapkan kebijakan tidak jelas.
\end{abstract}

Kata Kunci: Implementation Trap Of Policy, Sistem Zonasi, PPDB

Citation : Mustari, N., Hardi, R., \& Muhiddin, A. (2021). Model Implementation Trap of Policy New Student Acceptance Zoning System in Makassar City. Journal of Government and Civil Society, 5(1), 91-106. 


\section{INTRODUCTION}

More flexibility and new governance processes are needed for incorporating and increasing community developments, as well as accessing the capacity of all societal sectors to improve education (Schröder \& Kruger, 2020). With the passing of time, the relationship between education and growth underwent many shifts, as did the viewpoints of those concerned (Yoo et al., 2019). Education is still a policy issue, whether indirectly or directly. What is and is not taught, how children are taught, and how educational systems are structured are all profoundly social issues. Education cannot be isolated from larger viewpoints on the society in which it is placed (Bell, 2020). Both parents' educational preferences for their children and social interaction with peers are critical mechanisms (Figlio et al., 2019; Harakan, 2017).

Improving the quality of education is the main goal that must be built by all elements of Education to produce creative human resources in the face of the challenges of the times. Although working conditions have a limited effect on educational results, the mediating position of employability and faculty engagement is important (Budiharso \& Tarman, 2020). All educational resources cannot function optimally if they are not supported by the availability of human resources. Educational institutions need to carry out a strategic, integrated, interrelated, and comprehensive human resources education planning through the management of education human resources in determining the desired movements of educators and education personnel in the future (Hasnadi, 2019). Educational institutions are a means to serve consumers in the form of students and communities from various fields; both services in the way of physical buildings and services inadequate facilities, quality, and professional teachers.Education's primary function is to create knowledge accumulated by community groups and control various aspects of people's lives. Therefore, educational services are needed to provide services to develop better students. Strengthening good social values by providing good educational services will establish a suitable educational mechanism and ensure Education.The national education development strategy is to expand access to quality education. Quality education will be obtained in quality schools, and quality schools will produce qualified students (Syamsuriyanti \& Sukirno, 2018).

The Government's efforts to improve education equality are one of them through school zoning programs. Zoning programs began to be implemented from the lowest education level, namely kindergarten to higher Education (Safarah \& Wibowo, 2018). The zoning system allows public schools to be prepared to provide quality education services equally to community members in a particular area so that the "best students" do not have to look for the "best schools" located far from where they live. The PPDB zoning mechanism allows schools to accept prospective students with large academic ability gaps and outstanding learners must study with those who are experiencing learning obstacles 
(Andina, 2017).The PPDBwith Zoning System has implications for setting up schools equal in quality to schools that have been considered excellent schools or favorite schools.PPDB's zoning system regulates public schools owned by local governments to accept prospective students domiciled in the nearest zone radius of the school at least $90 \%$ (Ninety percent) of the total number of students received. The local government sets the tightest zone radius according to school-age children's availability in the area and the learning group's capacity at each school.

However, schools can accept new students outside the nearest zone for achievement reasons for at most $5 \%$ and at most $5 \%$ for specific reasons, such as parental/guardian domicile transfer. This zoning system in PPDB can take place in a more objective, transparent, accountable, nondisruptive, equitable, and equitable manner following the 1945 Constitution that every citizen deserves a decent education. The education system in modern society is supposed to fulfill two absolute functions that first equip individuals to participate in social, economic, and political life. Second, to provide the most comprehensive access to education to equal the quality of Education. These two key elements are the basis of the emergence of equalization of Education to improve the quality of Education. The zoning system policy changes the paradigm in the perceptions of education policy, most especially the stakeholders. The essence of the regulation accommodated by the Minister of Education and Culture causes the various implementation of regulations in the regions. This is because it provides flexibility for regencies to adopt regulations made due to geographical, demographic, and spatial material (Bakar et al., 2019)

Previous studies have revealed that the implementation of a new admissions policy based on the zoning system shows that the dichotomy of favorite and un-favorite schools cannot be eliminated not only because of the mindset of the community, but also because of the policies of local governments that do not support, as well as the unpreparedness of local governments in providing quality educational facilities and infrastructure in all schools (Mahyani et al., 2019; Purwanti et al., 2018). The application of New Student Admissions zoning (PPDB) for the 2019/2020 school year imposed by the Makassar City Government through the Education Office poses problems and even causes unrest for parents. In addition, there are concerns that housing is prone to cause social problems especially related to the motivation of achievement. The PPDB zoning mechanism allows schools to accept prospective students with large academic skills gaps. Outstanding students should study with those with learning barriers (Andina, 2017).

In the zoning system each school has its quota based on the number of classes it has. One type only accommodates a maximum of 30 to 35 in one level multiplied by the number of school classrooms. So if the number of residents in one area is more, then the furthest prospective students will indeed be eliminated (Hasanuddin, 2019). Then the impact of 
this policy has been examined by ArisNurlailiyah who concluded that the zoning system removes the school dichotomy between favorite and ordinary, encouraging children to be close to family and efficient in distance and cost (Nurlailiyah, 2019). Furthermore, the evaluation of the implementation of the admissions zoning system conducted by AmirullahDatuk found that there is still a gap between the state and private sector, the lack of synergy between the central and local governments in preparing professional educators spread across existing schools, the supply of learning facilities and playrooms in schools that have not yet been dissected (Datuk, 2020).

Furthermore, Research conducted by Põder et al., (2017)entitled Does School Admission by Zoning Affect Educational Inequality? A Study of Family Background Effect in Estonia, Finland, and Sweden. It is claimed that the zoning system negatively affects the improvement of the quality of Education in Estonia, Finland, and Sweden. But in this study, it is not mentioned what the problem is in the system. Then, in 2018 (Bintoro, 2018) Examined Public Perception of The Implementation of School Zoning Policy in Admission of New Students (PPDB) at high school level in 2017/2018 in Samarinda City. The results showed that the implementation of school zoning policies caused turmoil in the community. Limited socialization time, Lack of understanding of PPDB mechanisms with a zoning system, and uneven educational standards are obstacles to its implementation in the field. Then, Safarah \& Wibowo (2018) researched zoning programs in elementary schools to equalize education quality in Indonesia. The results revealed that the school zoning program has implications in education, e.g., equalization of Education and concerning environmental impacts such as traffic congestion, air pollution, physical and child health, and reliance on motor transportation.From the research that has been done, there has not been and needs to be examined more deeply about the trap of implementation in the implementation of the New Student Admissions policy based on the Zoning System. The inhibiting factor for policy implementation is the implementation trap (Schiller, 2017). The meaning of implementation trap is Incomplete specifications, Improper institution, Conflict of purpose, Incentive failure and Conflict of instructions. Instructions that are unclear and contradict each other can confuse policy implementers in running a program.(Howlett \& Ramesh, 2003).

The purpose of the research is to describe the obstacles to policy implementation, the characteristics of the problem of New Student Admissions zoning system, the carrying capacity of regulations and non-regulations that affect the application of PPDB zoning system, as well as the trap of implementation on zoning system policy. 


\section{METHOD}

This study uses a qualitative descriptive approach with the type of case study research combined with triangulation techniques. The first is qualitative data analysis; a data reduction process focused on the selection, simplification, randomization, and transformation of rough data from field records; in this process, selected data relevant to the focus of research and data that does not meet the criteria. The data reduction process is carried out gradually during and after data collection until the report is composed. The second is the presentation of data, which prepares a set of information into a statement that allows the withdrawal of conclusions. Furthermore, the data is presented in narrative text, initially scattered and separated at various sources of information, then classified according to the theme and analysis needs. At this stage, the data collection results in the field after reduction are arranged in the form of statements that can be used as sources of information in the preparation of reports. The third is the withdrawal of conclusions based on the reduction and presentation of data. The withdrawal of the findings takes place gradually from the general judgment at the data reduction stage, then becomes more specific at the presentation stage of the data, and more specifically at the actual conclusion drawing stage. Four. Develop a Model for Implementing New Student Acceptance Zoning System in Makassar City

Data analysis is carried out at all times in the field on an ongoing basis. It starts with clarifying data to achieve consistency and continued theoretical abstractions of information in the area, taking into account questions that are likely to be considered fundamental and universal. The description or information about the reviewed objects' events still finds the degree of internal coherence, reasonableness, and relates to factual and realistic circumstances. By comparatively comparative observation findings and deepening meanings, continuous data analysis is obtained simultaneously throughout the research process. Analyze this qualitative data using inductive methods. Some of the the indicators in this research were analyzed using software Nvivo12 Plus, Also, it analyzes and describes the implementation of government policies regarding the new student admission based on the zoning system by using theories and concepts related to Public Policy Science. The research data that has been collected through interviews with respondents is then processed through Nvivo, the interview data is matched to the predetermined research indicators. The coding process is adapted to the theory that has been used. Classifying data as a retranslation process of data coding, classifying process using Nvivocrosstabulation, crosstabulation as a comparison process of each data. The last stage in the nvivo analysis process is the display of data in the form of graphs and tables, this analysis model in Nvivo is referred to as five steps analysis (Woolf \& Silver, 2018). 


\section{FINDINGS}

\section{Zoning System in Makassar City}

The term "zoning" began to be used in 2017 in the setup of the New Student Admissions system (PPDB), which refers to Regulation of the Minister of Education and Culture No. 14 of 2018 on Admission of New Students in Kindergartens, Elementary Schools, Junior High Schools, High Schools, Vocational High Schools, or other equivalent forms.

PPDB's zoning system regulates public schools owned by local governments to accept prospective students domiciled in the nearest zone radius of the school at least $90 \%$ (Ninety percent) of the total number of students received. The local government sets the tightest zone radius according to school-age children's availability in the area and the learning group's capacity at each school. However, schools can accept new students outside the nearest zone for achievement reasons for at most $5 \%$ and at most $5 \%$ for specific reasons, such as parental/guardian domicile transfer. This zoning system in PPDB can take place in a more objective, transparent, accountable, nondisruptive, equitable, and equitable manner by the 1945 Constitution that every citizen deserves a decent education.

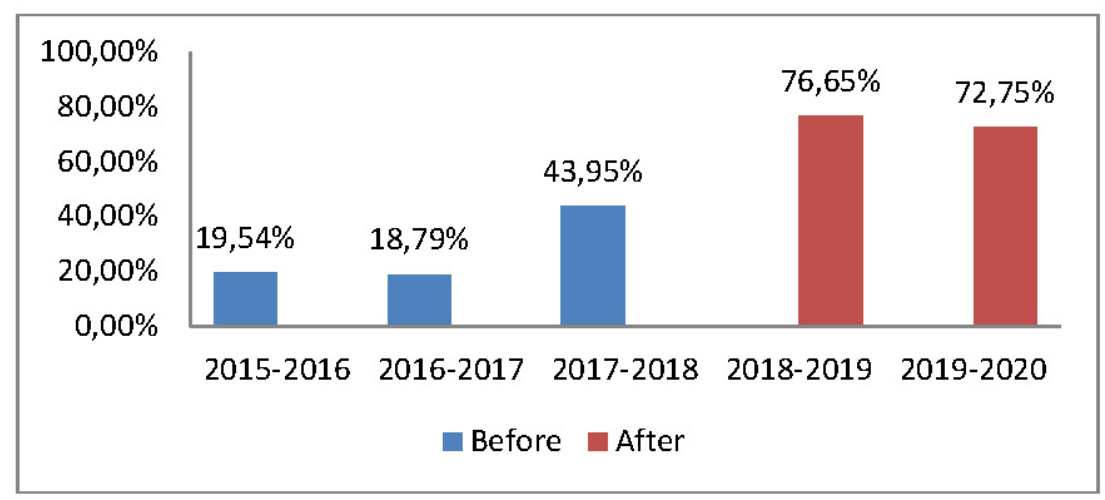

Figure1. New Students of Makassar City Domicile/Zoning Line 2015-2020 Source : Processed by the Authors (2020)

From the above data suggesting that new student admissions on zoning lines have performed well, it is seen on the chart the number of new students on the zoning path continues to increase from year to year. It's just that in the 2019-2020 school year, new students' zoning pathways decreased slightly due to the addition of student quotas on the achievement pathway.

The zoning system's implementation requires prospective students to attend schools that have the nearest radius of their respective domiciles. Students can have a maximum option of three schools, with the school's record still having a student slot and being within the student's zoning area. Based on Permendikbud, number 51/2018 regulated 
PPDB through zoning. The selection of prospective new students is made by prioritizing the nearest residence distance to the school within the designated zoning. The closest residence distance is calculated based on the mileage from the Village Office to the school. If the length of residence is the same, then the priority is the prospective students who register early.

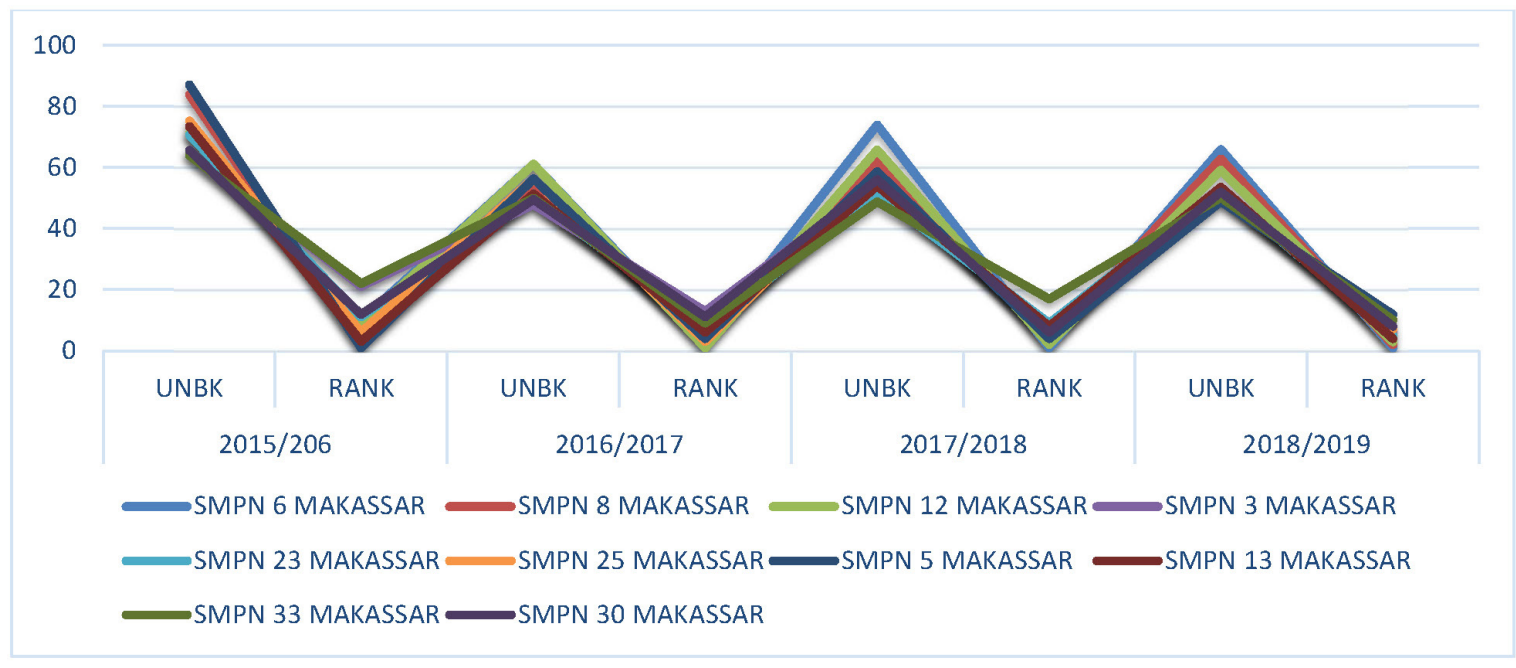

Figure 2. Favorite Junior High School UNBK Achievement In Makassar City 20152019

Source : Processed by the Authors (2020)

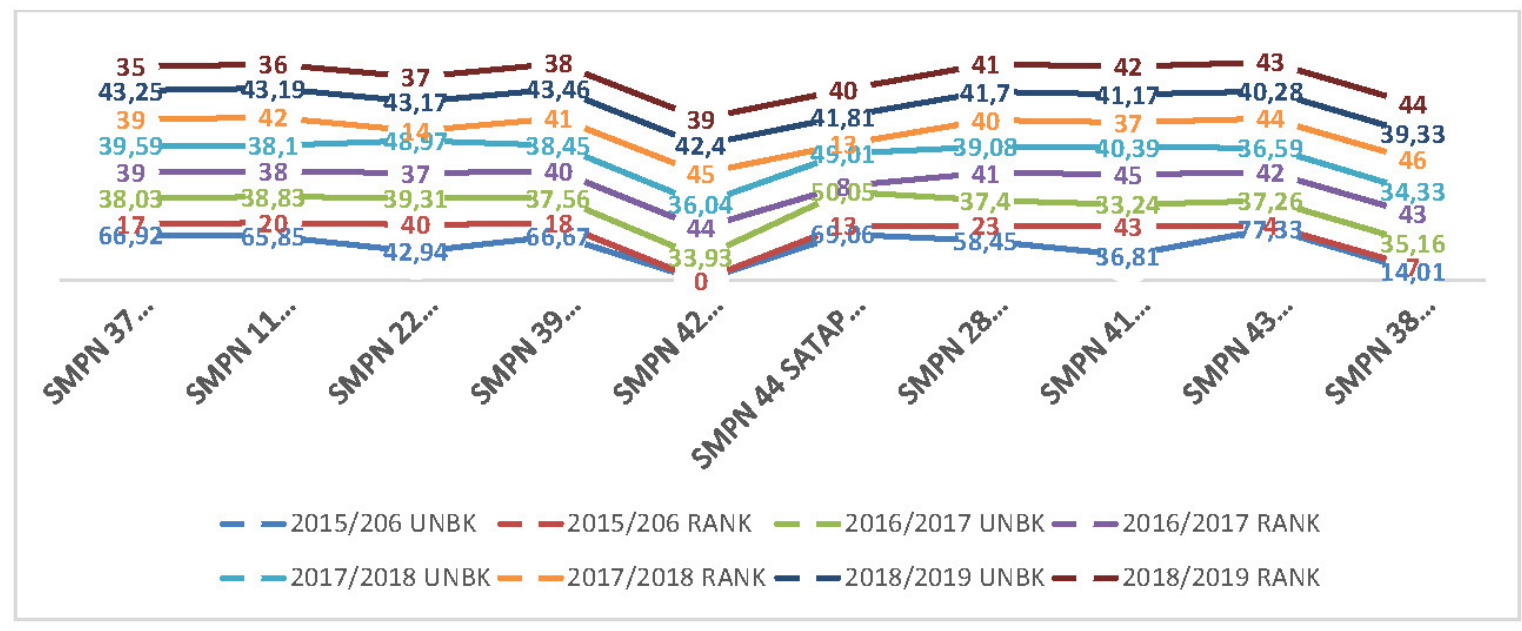

Figure 3. Non Favorite Junior High School UNBK Achievement In Makassar City 2015-2019

Source : Processed by the Authors (2020) 
Based on the figure above, it is seen that SMPN 6 has the highest UNBK value. The zoning system is based on providing opportunities for equalization of the quality of Education in schools. By the basis in The Indonesian Rebuplik Law No. 20 of 2003 on the National Education System explained that the national education system must ensure equalization of educational opportunities, quality improvement, and relevance of education management to face challenges following the demands of local, national, and global life changes so that education reform is necessary and planned, directed, and sustainable. The opportunity to equalize the school's quality is felt by schools that are notable, lacking quality, and still have many shortcomings in both the system and its infrastructure facilities. The facilities and infrastructure of a school is an integral part of the quality assurance of Education; in the Law makes it clear that each unit of formal and nonformal Education provides facilities and infrastructure that meet the needs of Education following the growth and development of physical potential, intellectual intelligence, emotional social, and educational obligations. Schools that have an increase in the number of students, the automatic school will improve to be better so that the quality of Education and schools become equal.

Another supporting factor is to provide the broadest possible opportunity for citizens to get the best education services because every citizen has the same right to obtain a quality education following the principle of organizing Education that is empowering all components of society through participation in the implementation and control of the quality of education services. The Government's job is to manage Education that aims to ensure people's access to adequate, equitable, and affordable education services. Education management is based on national policy in education following the provisions of existing laws and regulations.

The policy of the Education Office in Makassar city in the admission of new junior high school students still refers to the provisions of Regulation of the Minister of Education and Culture No. 14 of 2018 on the acceptance of new students in kindergarten, elementary school, junior high school, high school, vocational school or other equivalent forms. While in the Regulation of the Minister of Cultural Education No. 20 of 2019, three PPDB registration lines include zoning lines, achievement pathways, and parental/guardian duty transfer lines. For zoning lines at least $80 \%$ of the school's capacity, achievement pathways are $15 \%$, and parent/guardian shift lines at most $5 \%$. Regarding zoning the selection of new students for the 10th grade of SMA Negeri, the local Government must accept prospective students at a radius of $90 \%$ zone. In comparison, outside the site's radius receive at most $5 \%$ for achievement pathways and $5 \%$ for the specific reason path of the total amount received. While in the Regulation of the Minister of Cultural Education No. 20 of 2019, three PPDB registration lines include zoning lines, achievement pathways, and parental/guardian duty transfer lines. For zoning lines, at least $80 \%$ of the school's 
capacity, achievement pathways are $15 \%$, and parent/guardian shift lines at most $5 \%$. Of course, this is a problem for prospective new students in selecting target schools.

\section{Characteristic Problems Implementing Zoning System}

Zoning policies are beyond the expectations of society in general. This is because the community wants a quality school for its children. When choosing a school, the first thing that determines the most is the school's quality, and the location is the last consideration. Furthermore, quality schools by ordinary people are labeled as favorite schools. Based on the results of Amarin's research, et al. (2016:1) shows the main factor in choosing a school is the level of school favorites. Those factors even beat other factors, such as facilities and teachers. There is a difference between the community and the Government through the policy of the zoning system in terms of school selection. Not only the city, but the school also can not choose the desired students.

\section{Characteristic Zoning System Policy}

The policy of the Office of Endidikan in Makassar city in the admission of new students still refers to the provision stipulated by the Minister of Education and Culture No. 14 of 2018. There are kindergartens, elementary schools, junior high schools, high schools, vocational schools, or other equivalent forms to accept new students. Meanwhile, in the regulation of the Minister of Cultural Education No. 20 of 2019, three registration lines include zoning lanes, restation lines and parental/guardian shift lines. For zoning lines at least $80 \%$ of the school's capacity, achievement pathways are $15 \%$, and parent/guardian shift lines at most $5 \%$.

About the issue of zoning the selection of new students for the 10th grade of SMA Negeri, the local Government is obliged to accept prospective students there is a radius zone of $90 \%$, while for outside the radius of the site receives at most $5 \%$ for the achievement path and $5 \%$ for the specific reason path of the total amount received. Meanwhile, in the regulation of the Minister of Cultural Education No. 20 of 2019, three GDP registration lines include zoning pathways, achievement pathways, and parental/guardian duty transfer pathways. For zoning lines at least $80 \%$ of the school's capacity, achievement pathways are $15 \%$, and parent/guardian shift lines at most $5 \%$. Of course, this is a problem for prospective new students in selecting target schools.

\section{Policy Implementation Framework}

PPDB Zoning System Policy in Makassar allows equal treatment efforts in every school to give the best to its citizens. Ppdb Zoning System needs to be supported and followed up with the development of an education quality zoning system, where the Government 
must prepare good schools in an area to provide quality, equitable and equitable education services. In one zoning quality, the education scheme is designed as a medium and longterm program to prepare schools (state) with relatively the same quality, at least in specific zones or regions. The Government ensures that there are schools with qualified teachers supported by complete educational infrastructure and learning facilities by the established standards in one particular zone.

In its implementation, the basis or basis of zone/region development can be distinguished into 2 (two) types, namely:

1. Zone-Based Administrative Limits. Administrative boundaries develop areas based on education services by bureaucracy in a tiered way from central to regional. Administrative boundaries consist of: national, provincial, district/city, sub-district, and village/village.

2. Theme/Substance Based Zone. Theme/substance boundaries are regional developments based on region characteristics based on geographic and demographic indicators. Some theme / substance consists of a service zone, cover zone, forest zone, residential zone, watershed zone (WATERSHED), etc. Substantively, Education is one of the service zones for every citizen that can be managed in the configuration of zones or regions either by administrative limits of Government or based on the characteristics of the theme/substance of the region/zone. Synchronization of two interests, namely PPDB Zoning and Education Quality Zoning, needs to be developed and implemented in a balanced and sustainable manner.

PPDB zoning in Makassar city was created to provide equitable, quality, and honest education services by prospective students' geographical and demographic conditions. In contrast, the Education Quality Zone was designed to give even, quality, and quality education services by mapping the quality of Education following the National Standard of Education (SNP) through feasibility assessment through accreditation activities. By synchronizing these two perspectives, it will give birth to schools that meet the SNP in each region that are ready to accept and serve the various characteristics of the students to produce graduates by the demands of the competency standards of graduates at every type and level of Education in Makassar city area.

By-Law No. 20 of 2003 on the National Education System, the Education Service Zone system is distinguished into three things depending on who is served and the context of the service, namely:

1. Community Education Services. This service is done through a multisector approach by considering the role of society in supporting and actively participating in providing 
educational services. The community is the user of output (output) and educational outcomes to positively impact or impact the overall development.

2. Children's Education Services. This service is done through a multisector approach that sees children as potential successors to the nation's generation, who must be ensured to access educational services at all levels of education.

3. Education Services of Students. This service is done with a sectoral approach in the field of Education. Every citizen who enters the Education System, either Formal or Non-Formal, must be served as a potential source of input to fill and continue development in their respective areas and the wider region.

\section{The Implementation Trap of Policy}

Policy implementation is an attempt to implement policy decisions. Variables that affect the achievement of formal goals in the entire implementation process. According to Mazmanian and Sabatier, the three factors Tasmanian and Sebatier put forward are the ease of a problem to be controlled, the policy implementation process's politicization, and non-legal variables that affect the policy implementation process (Kadji, 2015).The guarantee of smooth implementation of the policy is well-done dissemination. The terms of management of policy dissemination are four, namely: 1) the respect of the public's members towards the government's authority to explain the need to comply with the laws made by the authorities morally; 2) the awareness to accept the policy. Understanding and willingness to accept and implement policies are realized while systems are considered logical; 3) the belief that the policy is made lawful; and 4) the understanding that although at first a policy is deemed to be controversial, but over time it is considered to be something reasonable to implement (Akib, 2010).Several inhibitory factors can also thwart policy implementation. These aspects are commonly referred to as the implementation trap of policy trap (Howlett \& Ramesh, 2003). Implementation trap of policy in Makassar City analysis through nvivo12 plus application with three indicators namely Limited Resource Administration, Ineffective Communication and limited competence. 


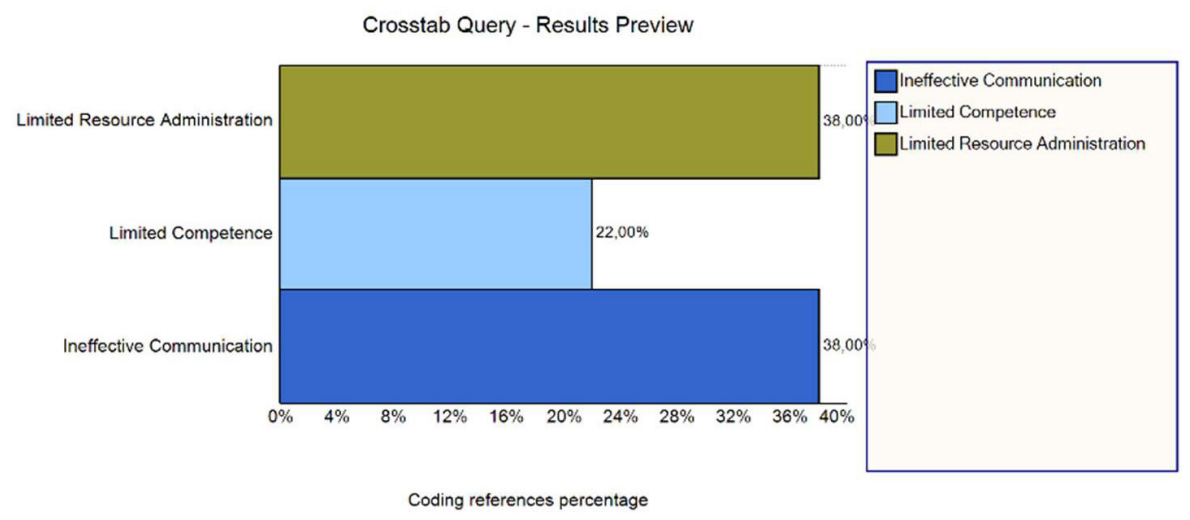

Figure 4. The Implementation od Zoning Policy in Makassar City

The figure above reveals that the Limited Resource Administration and Ineffective Communication are the highest indicators in the implementation of zoning policy in Makassar City. Then limited competence gets a percentage of $22 \%$ in the performance of the zoning policy.

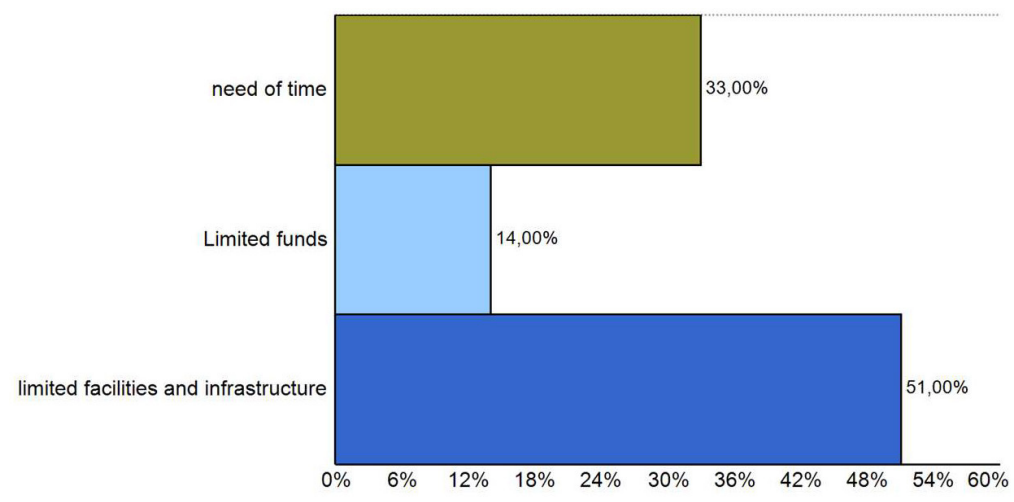

Coding references percentage

Figure 5. Limited Resource Administration

The graph in figure 5 shows that the limitations of facilities and infrastructure are the highest percentage indicators in the limited resource administration, which is due to the limitations of facilities to change the formation of the number of learning groups so that some schools are not prepared for zoning policies in the acceptance of new students. Zoning policy on the acceptance of new students in Indonesia encountered many challenges; the analysis results in figure 2 suggested that zoning policy still takes time to produce maximum results. The next indicator is a budget limitation that gets a percentage 
of $14 \%$; this is due to the zoning system applied to save transportation costs because the school's location is around the house. So for the cost limitation component is in the safe category because it facilitates access in schools.

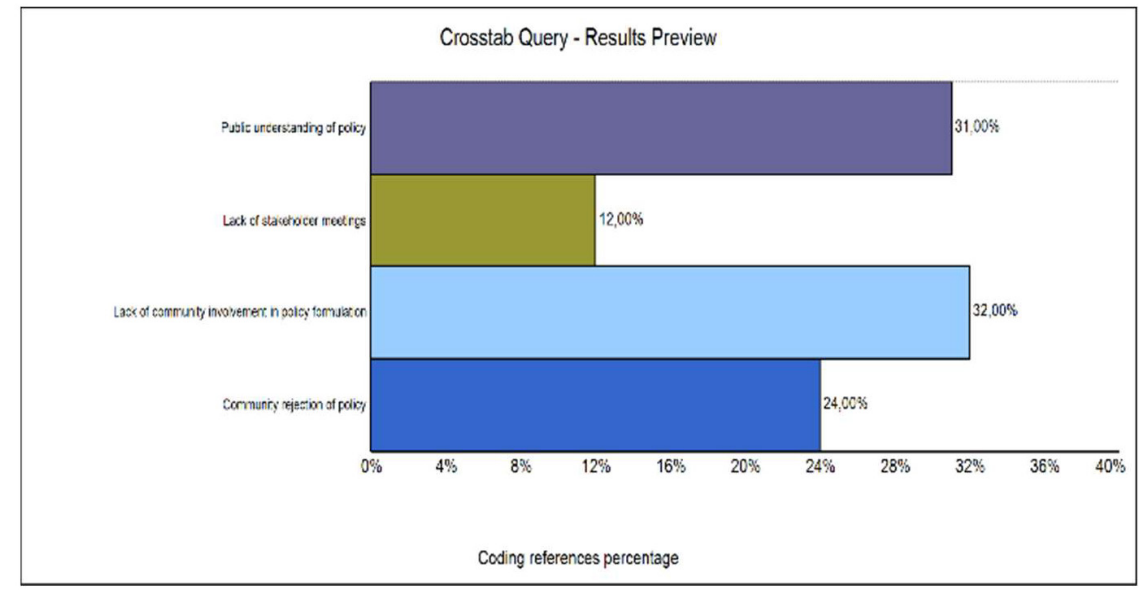

Figure 6. Ineffective Communication

Ineffective communication is the cause of the Lack of community involvement in policy formulation, which is the highest percentage indicator, $32 \%$ because of the Lack of community involvement in policy formulation. Then the public understanding of policy gets a percentage of $31 \%$, the public's knowledge of school zoning policy is still limited so that many cases of outstanding students not getting seats in public schools are due to the little ability of parents of students towards the acceptance of new students with the zoning system. Also, there are some complaints and dissatisfaction with the approval of new students with the zoning system. It is seen in figure 3 that the community rejection of policy gets a percentage of $24 \%$. However, in this case, it is cool that the denial of this zoning policy is not massif and can still be overcome by the Government. Finally, the ineffectiveness of communication in the zoning system's implementation is due to the Lack of meetings between stakeholders in the face of school zoning policy issues. Figure 3 shows that the Lack of stakeholder meetings gets $12 \%$ in influencing the ineffectiveness of communication. It indicates that the stakeholders have implemented stakeholder meetings in zoning policy discussions. 


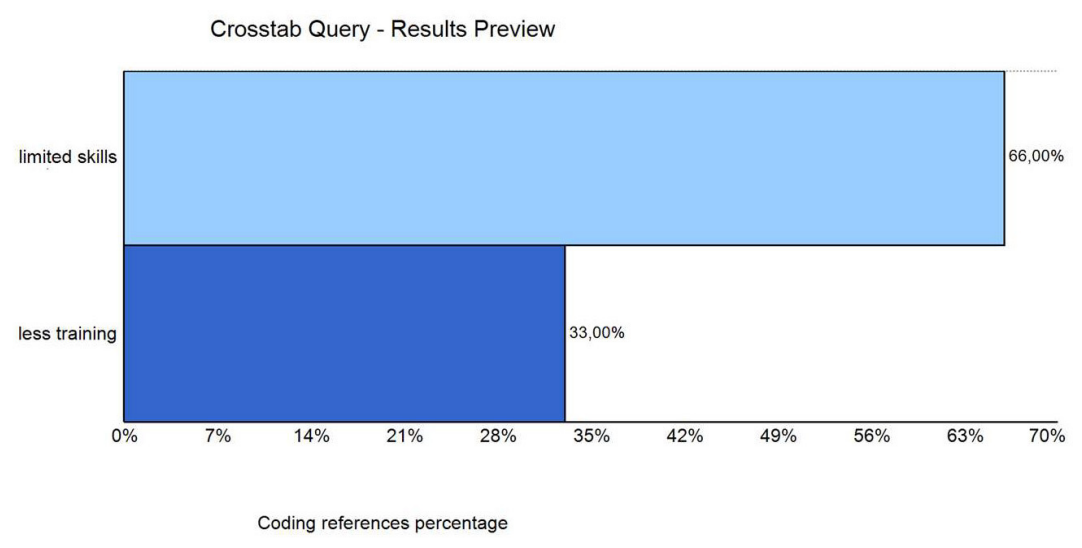

Figure 7. Limited Competence

The above data shows that limited competence is owned by new admissions executives with a zoning system due to lack of training and limited skills owned by new admissions executives, it appears that limited skills get a percentage of $66 \%$ while less training $33 \%$. Proper hr training and development can have a good effect on the implementing committee. Then employees can develop themselves and understand the intricacies of the implementation of new students' admissions by zoning methods to understand the policies and regulations that apply.

\section{CONCLUSION}

Characteristics problem of Accepting New Students zoning system: Infrastructure readiness problems for online registration, Lack of socialization of PPDB system to prospective students and parents, thus confusing. Technical instruction (juniors) is less explicit and poorly understood by the community, and sometimes the registration receiving officer also does not understand. Transparency of quotas per zoning is often a question of society, including the percentage of learning groups and capacity. The uneven distribution of public schools in each sub-district and village, while many areas were zoning divisions at first, was based on the sub-districts administrative area. Some prospective students are not accommodated because they cannot apply to any school.

The limitations of competencies owned by the implementation of new students' admissions with a zoning system due to the Lack of training and limited skills possessed by the performance of new students' performance, it is seen that limited skills get a percentage of $66 \%$ while less training $33 \%$. Proper hr training and development can have a good effect on the implementing committee. Then employees can develop themselves and understand the intricacies of the implementation of new students' admissions by zoning methods to understand the policies and regulations that apply. 
The implementation trap of policy, the policy objective is too vague or broad to be converted into action, the target specification is not clearly defined due to weak guidelines on how goals can be achieved, or undefined standards or actions to be taken, either in implementing, or the target community. Finally, problems also arise when the chain of responsibility for implementing a policy is unclear.

The implementation of the zoning system policy should be implemented in a balanced manner, the admission of new students is not only by region but must be seen from achievement, so it is balanced between the zoning path and the achievement path. Furthermore, the Government should also pay attention to the equalization of the quality of educator resources and to increase the ratio of educators in disadvantaged schools

\section{REFERENCES}

Akib, H. (2010). Implementasi Kebijakan: Apa, mengapa dan Bagimana. Jurnal Adminstrasi Publik, 1(1), 1-11. https://media.neliti.com/media/publications/97794-IDimplementasi-kebijakan-apa-mengapa-dan-b.pdf

Andina, E. (2017). Sistem Zonasi dan Dampak Psikososial Bagi Peserta Didik. Bidang Kesejahteraan Sosial Puslit Badan Keahlian DPR, IX(14), 9-12.

Bakar, K. A. A., Supriyati, Y., \& Hanafi, I. (2019). The Evaluation of Admission Student Policy based on Zoning Sys-tem for Acceleration Education Quality in Indonesia. Journal of Management Info, 6(2), 19-24. https:// doi.org/10.31580/jmi.v6i2.883

Bell, L. A. (2020). Education Policy: Development and Enactment-The Case of Human Capital. In Handbook of Education Policy Studies: Values, Governance, Globalization, and Methodology (pp. 1-414). Springer, Singapore.

Bintoro, R. F. A. (2018). Public Perception Regarding Policy Implementation On School Zoning Policy In The Acceptance Of High School New Students Year 2017/2018 In Samarinda. Jurnal Riset Pembangunan, 1(20), 48-57.

Budiharso, T., \& Tarman, B. (2020). Improving quality education through better working conditions of academic institutes. Journal of Ethnic and Cultural Studies, 7(1), 99-115. https://doi.org/10.29333/ejecs/306

Datuk, A. (2020). Sistem Zonasi Sebagai Solusi Bagi Orang Tua untuk Mendapatkan Pendidikan Anak yang Bermutu di Kota Kupang. Innovative Education Journal, 2(2), 1-13.

Figlio, D., Giuliano, P., Özek, U., \& Sapienza, P. (2019). Long-Term Orientation and Educational Performance. American Economic Journal: Economic Policy, 11(4), 272-309. https:// doi.org/10.1257/ pol.20180374

Harakan, A. (2017). Efektivitas pelaksanaan kebijakan sistem kelas tuntas berkelanjutan di kabupaten Gowa. Aristo, 5(1). 
Hasanuddin, M. (2019, July 26). Warga Makassar keluhkan Penerapan sistem zonasi DB 2019. Antara News. htts:// makassar.antaranews.com/berita/128265/wargamakassar-keluhkan-eneraan-sistem-zonasi-db-2019.

Hasnadi. (2019). Perencanaan Sumber Daya Manusia Pendidikan. Jurnal Studi Ilmu-Ilmu Keislaman, 10(2), 141-148. http:/ / ejournal.staindirundeng.ac.id/index.php/bidayah/ article/view / 270/178

Howlett, M., \& Ramesh. (2003). Studying Public Policy/ : Policy Cycles and Policy Subsystems. Oxford University Press.

Kadji, Y. (2015). Formulasi Dan Imlementasi Kebijakan Publik: Kepemiminan dan Perilaku Birokrasi dalam Fakta Realitas. UNG Press Gorontalo.

Mahyani, E. R., Wahyunengseh, R. D., \& Haryanti, R. H. (2019). Public Perception of Zoning School Policy in Surakarta Public Senior High Schools. 343(Icas), 274-278. https:/ / doi.org/ 10.2991/icas-19.2019.56

Nurlailiyah, A. (2019). Analisis Kebijakan Sistem Zonasi Terhadap Perilaku Siswa SMP di Yogyakarta. Realita, 17(1), 13-22.

Põder, K., Lauri, T., \& Veski, A. (2017). Does School Admission by Zoning Affect Educational Inequality? A Study of Family Background Effect in Estonia, Finland, and Sweden. Scandinavian Journal of Educational Research, 61(6), 668-688. https:// doi.org/10.1080/00313831.2016.1173094

Purwanti, D., Irawati, I., \& Adiwisastra, J. (2018). Efektivitas Kebijakan Penerimaan Peserta Didik Baru Sistem Zonasi Bagi Siswa Rawan Melanjutkan Pendidikan. Dinamika, 5(4), 1-7. https://doi.org/http://dx.doi.org/10.25157/dinamika.v5i4.1737

Safarah, A. A., \& Wibowo, U. B. (2018). PROGRAM ZONASI DI SEKOLAH DASAR SEBAGAI UPAYA PEMERATAAN KUALITAS PENDIDIKAN DI INDONESIA. Lentera Pendidikan/ : Jurnal Ilmu Tarbiyah Dan Keguruan, 21(2), 206. https://doi.org/ 10.24252/1p.2018v21n2i6

Schiller, M. (2017). The implementation trap: the local level and diversity policies. International Review of Administrative Sciences, 83(2), 267-282. https://doi.org/10.1177/ 0020852315590204

Schröder, A., \& Kruger, D. (2020). Social Innovation as a Driver for New Educational Pratices: Modernising, Reparing and Transforming the Education System. Nature/ Sustainability, 11(4), 1-14. https://doi.org/https://doi.org/10.3390/su11041070

Syamsuriyanti, S., \& Sukirno, S. (2018). Faktor determinasi profesionalisme guru. Harmoni Sosial: Jurnal Pendidikan IPS, 4(2), 197-211. https:// doi.org/10.21831/hsjpi.v4i2.10321

Woolf, N. H., \& Silver, C. (2018). Qualitative Analysis Using Nvivo, The Five Level QDA Method. In Routledge. New York and London: Routledge.

Yoo, S. S., Mosrur, R., Lee, E., \& Andrea, D. T. (2019). Development as education for social justice. Asia Pacific Education Review, 20(2), 259-272. https://doi.org/10.1007/ s12564-019-09603-2 